\begin{tabular}{|c|c|}
\hline \multirow{3}{*}{ 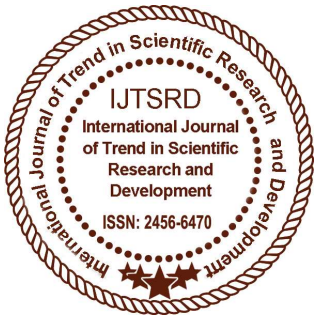 } & $\begin{array}{l}\text { International Journal of Trend in Scientific } \\
\text { Research and Development (IJTSRD) }\end{array}$ \\
\hline & International Open Access Journal \\
\hline & ISSN No: 2456 - 6470 | www.ijtsrd.com | Volume - 2 | Issue - 1 \\
\hline
\end{tabular}

\title{
Studies on Chemical Composition and Antifungal activity of essential Oil of Ocimum gratissimum L. growing wildly in Chamba (Tehri Garhwal) Uttrakhand, India
}

A. M. Painuly

Department of Chemistry, Government Post Graduate College, New Tehri, Tehri Garhwal, Uttrakhand

\section{J. S. Jangwan}

Department of Chemistry, H.N.B. Garhwal Central University Campus Badsahithoul, Tehri Garhwal, Uttrakhand, India

\section{ABSTRACT}

Essential oil obtained from aerial parts of Ocimum gratissimum collected from Chamba (Tehri Garhwal), Uttrakhand, India by hydrodistillation, was analyzed by GC and GC-MS for its chemical profile, and evaluated for antifungal activity. The analysis revealed the presence of 35 compounds which constitutes $96.27 \%$ of the total oil. The major components of the oil were found to be eugenol (32.86\%), $\quad \alpha$-terpenolene $\quad(22.83 \%), \quad$ cis- 8 methylbicyclo $(4,3,0)$ non-3-ene $(9.08 \%)$, camphene (2.65\%), $\alpha$-phellandrene $(2.12 \%), \alpha$-pinene(1.56\%), $\beta$-bourbonene $\quad(1.46 \%), \quad \beta$-pinene $\quad(1.36 \%)$, carophyllene $(1.32 \%)$, dodecatetraene $(1.23 \%)$, 3cyclohexen-1-ol (1.15\%) and tert-butylbenzene $(1.02 \%)$. The essential oil exhibited good antimicrobial activity against few human pathogenic fungi.

Keywords: Ocimum gratissimum, essential oil, antimicrobial activity, fungi, eugenol.

\section{INTRODUCTION}

Due to their significant applications in flavor, perfumery and drug industry essential oils and their chemical components are in great demand. Their chemistry and medicinal properties constitute an interesting area of modern research all over the globe.

\author{
V. P. Joshi \\ Head, Analytical Sciences \& Corporate Quality \\ Assurance, Dabur India LTD., Sahibabad, Ghaziabad \\ R. P. Chamoli \\ House No-10, Lane No-2, Ashirwad Enclave, \\ Dehradun, Uttrakhand, India
}

The richest source of essential oils are the plants of the family Lamiaceae ( Syn- Labiatae) ${ }^{1}$. This family is reported to possess 252 genera and 700 species of plants $^{2}$. The genus ocimum is a prominent member of the Lamiaceae family comprising more than 150 species growing widely throughout the temperate region of the world $^{3}$. The species of the Ocimum commonly found in India are Ocimum ammericanum L. Ocimum canum, Ocimum basilicum, Ocimum gratissimum, Ocimum kilmandscharicum and Ocimum virade ${ }^{4}$. Ocimum gratissimum is a herbaceous plant which is indigenous to tropical region of the world mainly India and West Africa. Savannah and coastal parts of the Nigeria are also good source of this plant. It is cultivated in some countries like, Nepal, Bangladesh and Shri Lanka ${ }^{5}$. Various names such as clove basil, sweet basil, tea brush, scent leaf or fever plant etc. are in vogue for this plant in different part of the world. In India Ocimum gratissimum is generally known as Virddhu tulsi, Ram tulsi or Mala tulsi.

The diverse applications of Ocimum gratissimum in traditional system of medicine are well known in many countries ${ }^{5}$. In folk medicine it is commonly used in the treatment of upper respiratory tract infections, diarrhoea, headache, skin diseases, pneumonia, cough, fever and eye diseases ${ }^{6}$. Its activity against several species of bacteria and fungi 
has also been reported ${ }^{7}$. The plant is also used in the treatment of epilepsy and some other mental ailments ${ }^{8,9}$. Recently, it has been reported that the plant is useful as antidiabetic, antioxidant, anxiolytic, sedative, antinflammatory, hepatoprotective, antitumour, gastroprotective and hypolepidemic ${ }^{10}$.

Our general interest ${ }^{11-14}$ in the chemistry of essential oil and above mentioned important medicinal properties associated with Ocimum gratissimum gave an impetus to analyse and evaluate antifungal activity of the essential oil of this plant growing wildly in Chamba(Tehri Garhwal) region of Uttrakhand Himalaya. Due to favourable soil and climatic conditions Uttrakhand region is a storehouse of medicinal and aromatic plants. But despite this fact, very little attention has been paid to chemical investigation of plants of this area. Essential oils are mixture of various compounds which play a significant role in survival and defense of the plants containing them ${ }^{15}$. It is well documented that there is remarkable variation in the chemical composition of the essential oils according to genotype of the plant species and some other factores such as method of extraction, method of preservation, geographical origin and environmental conditions ${ }^{16}$.

On the basis of major chemical constituents of essential oil, Ocimum gratissimum is classified into some chemotypes such as Eugenol, Thymol and Geraniol $^{17}$ etc. Previous studies on chemical composition of Ocimum gratissimum from different regions indicated conspicuous changes in the chemical composition of its essential oil. In a study on essential oil of Ocimum gratissimum grown in Hyderabad presence of eugenol $(87.86 \%)$ as main component has been reported $^{18}$. In another study from Bangladesh thymol (58.2\%) was found to be major constituent $^{19}$. Presence of thymol $(27.33 \%)$ as main constituent of the oil was found in a study conducted in $\mathrm{Cuba}^{20}$ while in oil extracted in Ethopia eugenol $(57.4 \%)$ was reported as a main compound ${ }^{21}$. In the essential oil of Ocimum gratissimum from Benin pcymene (28.08-53.82\%) was the main compound ${ }^{22}$. The oil from Brazil ${ }^{23}$ and East Kenya ${ }^{24}$ eugenol was the main compound in the concentraction of $98 \%$ and $68 \%$ respectively.

\section{Experimental}

\section{Plant material and isolation of essential oil}

The aerial parts of Ocimum gratissimum L. were collected from a wild population during the flowering season in the month of March from the outskirt of Chamba (Tehri Garhwal), Uttrakhand which is located at an altitude of $1600 \mathrm{~m}$ above sea level.

The plant was botanically identified by the courtesy of Botany Department of HNB Garhwal University Campus, Badshahithaul, Tehri Garhwal, Uttrakhand and voucher specimen was deposited there at herberium section. The fresh aerial parts of the plant were hydrodistilled for 4 hours in a Clevenger type apparatus. Colourless oil with a pungent smell was obtained in $0.07 \%$ yield. It was dried over anhydrous sodium sulphate and stored in a sealed glass vial at $5^{0} \mathrm{C}$ in a refrigerator. The yield of the dried oil was $0.10 \%(\mathrm{~W} / \mathrm{W})$.

\section{GC and GC-MS analysis of the essential oil}

The oil was subjected to GC analysis using a 6890 series gas chromatograph(Agilent Technologies, USA) equipped with a HP-5 column $(30 \mathrm{~m} \times 0.25 \mathrm{~mm}$, $0.25 \mu \mathrm{m}$ film thickness) and flame ionization detector (FID), carrier gas: $\mathrm{N}_{2}$ at the flow rate of $1.2 \mathrm{ml} / \mathrm{min}$ and a split ratio of 1:100; temperature programme: initially at $50^{\circ} \mathrm{C}$ for $/ \mathrm{min}$, rising at $4^{\circ} \mathrm{C} / \mathrm{min}$ to $240^{\circ} \mathrm{C}$ and from $240^{\circ} \mathrm{C}$ to $270^{\circ} \mathrm{C}$ at $15^{\circ} \mathrm{C} / \mathrm{min}$. Injector and Detector temperature were held at $280^{\circ} \mathrm{C}$.

The GC-MS analysis of the oil was performed on 6890 series gas chromatograph interfaced with a 5973 network MSD, Agilent Technologies, USA mass spectrometer, operating on EI mode at $70 \mathrm{eV}$, with an ion source temperature of $230^{\circ} \mathrm{C}$. the $\mathrm{GC}$ was equipped with HP-5 MS capillary column $(3 \mathrm{~s} 0 \mathrm{~m} \mathrm{x}$ $0.25 \mathrm{~mm}, 0.25 \mu \mathrm{m}$ film thickness) from Agilent, USA with Helium as carrier gas at the flow rate of $1.9 \mathrm{ml} / \mathrm{min}$ and split ratio $1: 100$. Temperatures in oven injector and detector were programmed in the similar manner as described under GC analysis. The examination of the oil was also performed by the use of an Innowax capillary column (30m x $0.32 \mathrm{~mm}, 0.25$ $\mu \mathrm{m}$ film thickness) from Agilent, USA and employing the same GC-MS with helium as carrier gas at the flow rate $1.9 \mathrm{~mL} / \mathrm{min}$ and split ratio $1: 100$. The oven temperature was programmed as follows: initially at $50^{\circ} \mathrm{C}$ for $/ \mathrm{min}$, rising at $4^{\circ} \mathrm{C} / \mathrm{min}$ to $240^{\circ} \mathrm{C}$ and from $240^{\circ} \mathrm{C}$ to $250^{\circ} \mathrm{C}$ at $15^{\circ} \mathrm{C} / \mathrm{min}$. and subsequently held 
isothermal $(15 \mathrm{~min})$ at $250^{\circ} \mathrm{C}$. Injector and Detector temperature were held at $255^{\circ} \mathrm{C}$ and $280^{\circ} \mathrm{C}$, respectively.

The constituents of the oil (Table 1) were identified by comparison of relative retention indices with authentic standards on a BP-1 column ${ }^{25,26}$, peal enrichment of conjection with standards wherever possible and comparison of mass spectra with literature data ${ }^{27-32}$. The percentage composition was computed from GC peak areas.

\section{Antimicrobial screening of Essential oil}

The oil was evaluated for its in vitro antimicrobial activity against four fungal strains: Fusarium oxysporum, Fusarium solani, Macrophomina phaseolina, and Rhizoctonia solani. The antifungal activity of the oil was measured at four different concentration $(2.5 \%, 5 \%, 10 \%$ and $20 \%)$ by dissolving it in DMSO and using poison food technique ${ }^{33}$. Potato dextrose agar(PDA) medium was used as basal medium. Sterilized PDA medium $(20 \mathrm{ml})$ was placed in $98 \mathrm{~mm}$ petridishes and allowed to solidify. Then filter paper disc ( $8 \mathrm{~mm}$ diameter) was placed over the solidified medium and $100 \mu \mathrm{L}$ of the essential oil solution was applied on it by a micropipette. Thereafter, $8 \mathrm{~mm}$ disc of the fungal pathogen was taken with the help of a sterilized cork borer and inoculated at the centre of petridish. The inoculated petridish was kept for incubation at $27^{\circ} \mathrm{C}$ for 40 hours along with the petridish containing the fungus in the medium with DMSO(as control) without the essential oil. Each treatment was replicated four times. After the expiry of the incubation period radial growth of the fungus pathogen was measured. Data on percentage radial growth inhibition over the control as calculated by the formula of Bliss ${ }^{34}$.

Percentage inhibition over control $=\frac{\mathrm{C}-\mathrm{T}}{\mathrm{C}} \mathrm{X} 100$ where $\mathrm{C}=$ growth of the fungus in control; $\mathrm{T}=$ growth of the fungus in treatment. Results of the antifungal activity are given in Table 2.

\section{Results and Discussion}

During the present study, the fresh aerial parts of ocimum gratissimum L. upon hydrodistillation yielded essential oil in $0.10 \%$ yield $(\mathrm{W} / \mathrm{W})$. It is colourless liquid with a pungent smell. The physicochemical properties of the oil are as follows: Sp.gr. $0.9825\left(25^{0} \mathrm{C}\right), \mathrm{n}_{\mathrm{D}}^{25} 1.4835,[\alpha]_{\mathrm{D}}^{25}-15.8^{0}(\mathrm{EtOH}, \mathrm{c}$ 1.0 ), acid value 1.2 , ester percentage 4.5 and ester number 6.25 . In other studies the reported ${ }^{10,35}$ yield were between 0.21 and $0.70 \%$. These diversities may be the attributed to environmental conditions e. g. light, temperature, humidity which have a remarkable influence on the production of volatile compounds in plants and consequently, the yield and chemical composition of essential oils show a change according to locality ${ }^{36}$. In the present study the GC and GC-MS analysis of the essential oil revealed the presence of 35 compounds which constitute $96.27 \%$ of the total amount of the oil (Table 1). Concentration of eugenol (32.86\%) was found to be highest. Hence, it can be regarded as eugenol chemotype. Other main components of the essential oil are $\alpha$-terpenolene (22.82\%), cis-8-methylbicyclo(4,3,0)non-3-ene (9.08\%), camphene (2.65\%), $\alpha$-phellandrene $(2.12 \%)$, $\beta$-bourbonene $\quad(1.46 \%), \quad \beta$-pinene $\quad(1.36 \%)$, carophyllene $(1.32 \%)$, dodecatetraene $(1.23 \%)$, cyclohexen-1-ol (1.15\%.) $\alpha$-pinene $(1.02 \%)$ and tertbutylbeneze (1.02\%).

Antifungal activity of the essential oil was investigated under in vitro condition against the four fungi: Fusarium oxysporum, Fusarium solani, Macrophomina phaseolina and Rhizoctonia solani by poison food technique at concentration of $2.5 \%, 5 \%$, $10 \%$ and $20 \%$ in dissolving it in DMSO. Results of the antimicrobial study are presented in Table 2 . The study indicated that the oil showed good antifungal activity against all the above mentioned fungal strains and the activity increases with the increasing concentration of the essential oil. Thus, the activity is maximum at a concentration of $20 \%$ while it is minimum at a concentration of $2.5 \%$.

\section{REFERENCES}

1) S. Burt, "Essential oils: Their antibiotic properties and potential applications in food", Int. J. Food Microbiol., 94, 223-253 (2004).

2) C. Hedge, A global survey of the biogeography of the labiatae. In: R. M. Harley, T. Reynolds, Editors. Advances in Labiatae Science, U.K. Royal Botanical Gardens, Kew; 1992, pp 7-17.

3) K. H. Baser, The Turkish Origannum species. In: S.E. Kintzios, editor. Oregano: The genera Origannum and Lippia, Taylor and Francis, 2002, p. 109. 
International Journal of Trend in Scientific Research and Development (IJTSRD) ISSN: 2456-6470

4) A Dictionary of Indian Raw Material and Industrial products, The Wealth of India (Publication \& information Directorate), CSIR, New Delhi, Vol. V1l, pp80-89 (1996).

5) K. S. Prabhu, R. Lobo, A. A. Shirwaikar and Shirwaikar, "Ocimum gratissimum: A review of its chemical, pharmalogical and ethenomedicinal properties", The Open Complimentary Medicine Journal, 1, 1-15(2009).

6) F. D. Onajobi, J. Ethanopharmacol, 18, 311(1986).

7) T. T. Adebolu and S. A. Oliadimeji, Afri. J. Biotechnol., 4, 682-684 (2005).

8) M. Rabelo, E. P. Souza, P. M. G. Soares et .al., “ Antinociceptive properties of essential oil of Ocimum gratissimum L. (Labiatae) in mice, Braz. J. Med. Biol. Res., 6, 521-524 (2003).

9) A. C. Akinmoladun, E. O. Ibukum, A. Emmanuel, E. M. Obutor and E. O. Farombi, Phytochemical constituent and antioxidant activity of extract from the leaves of Ocimum gratissimum, Sci. Res. Essay, 2, 163-166 (2007).

10) Maria Karillyna Do Nascimento Silva, Victoria Regina De Alencar Carvalho and Edinardo Fagner Ferreira Matias; Chemical Profile of Essential Oil of Ocimum gratissimum L. and evaluation of Antibacterial and Drug resistance - modifying Activity by gaseous Contact Method, Pharmacogn. J., 8, 4-9 (2016).

11) Pran N. Kaul, Gopal R. Mallavarapu and R. P. Chamoli; "The Essential oil composition of Agelica glauca Roots, Planta Medica, 62, 80-81 (1996).

12) Virendra P. Joshi, Neeraj Kumar, Vikram Singh and R. P. Chamoli; "Chemical Composition of the Essential Oil of Centella asiatica (L.) Urb. from Western Himalaya", Natural Product Communications, 2, 587-590 (2007).

13) J. S. Jangwan, A. M. Painuly, V. P. Joshi and R. P. Chamoli, " Chemical compostion and antibacterial activity of phytochemical constituents in essential oil of Rosa brunonii, Indian Perfumer, 51, 53-55 (2007).

14) A. M. Painuly, J. S. Jangwan, V. P. Joshi and R. P. Chamoli, "Altitudinal Variation of Phytochemical Constituents in Essential Oil of Rosa brunonii (L), In: Phytochemicals: A Therapeutant for Critical Disease Management, D.
R. Khanna, A. K. Chopra, G. Prasad, D. S. Malik and R. Bhutani(Eds.), Daya Publishing House, Delhi, India, pp 157-161 (2008).

15) A. C. Saini, A. Sampaio, M. Souza, M. Heriques and M. Ramos, Oleos essentials: potential, antifungul, antiinflamatorio, Biotechnologia cienc desenvolv., 16, 38-43 (2000).

16) K. I. Suhr and P. V. Nielsen, Antifungal activity of essential oils evaluated by two different application techniques against rye bread spoilage fungi, J. Appl. Microbiol., 94, 665-674 (2003).

17) R. F. Vieira, R. J. Grayer, A. Parton and J. E. Simon, Genetic diversity of Ocimum gratissimum L. based on volatile oil constituents, flavonoids and RAPD markers, Biochem. Syst. Ecol., 29, 287-304 (2001).

18) A. K. Bhattacharya, P. N. Kaul and B. R. R. Rao. Indian perfumer, 40, 73-75 (1996).

19) M. Yusuf, J. Rosado, L. Mondello and L. Alcontres, Flavour fragrance J., 13, 163-166 (1998).

20) J. A. Pino, A. Rasado and V. Fuentes, J. Essential oil Research, 8, 139-141(1996).

21) N. Asfaw and B. Abegaz, Ethiop J. Sci., 12, 111113 (1989).

22) Benedicta G. H. Kpadonou Kpoviessi, Eleonore Yayi Ladekan, D. S. Salome Kpovilssi, Fernand Gbaguide, Boniface Yehouenou, Joelle QuetmLedercq, Gilles Gigueredo, Mansourou Moudachirou and Georges C. Accrombessi, Chemical variation of essential oil constituents of Ocimum gratissimum L. from Benin and impact on antimicrobial properties and toxicity against Artemia salina leach, Chemistry \& Biodiversity, 9, 139-150 (2012).

23) M. G. de Vasconcelos Silva, A. A. craveiro, F. J. abreu Matos, M. i. L. machado and j. W. alencar, Fitoterpia, 70, 32 (1999).

24) Lexa G. Matasyoh, Josphat C. Matasyoh, Francies N. Wachira, Miriam G. Kinyoa, Anne W. Thairu Muigai and Titus K. Mukiama, Chemical composition and antimicrobial activity of the essential oil of Ocimum gratissimum L. growing in Eastern Kenya, Afri. J. Biotechnol., 6, 760-765 (2007). 
25) E. Guenther, The Essential Oils, Vol 1, pp 227267, D. Van Nostrand Co. Inc., Princeton, N. J., U.S.A., 1948.

26) N. W. Davies, J. Chromatography, 503, 1-24 (1990).

27) W. Jennings and T. Shibamito, Qualitative Analysis of Flavour and Fragrance Volatiles by capillary Gas Chromatography, Academic Press. New York, 1980.

28) R. P. Adams, Identification of Essential oils by ion Trap Mass Spectroscopy, Academic Press. New York, 1989.

29) W. Pushan, G. Xuanliang, W. Fukuyama, I. Miura and M. Sugawara, Phytochemistry, 23, 2033-2038 (1984).

30) M. Kobayashi, M. Fujitcha and H. Mitsuhashi, Chem. Pharm. Bull., 32, 3370-3375 (1984).
31) M. Kaouadji, F. De Pachtere, C. Puget, A. Chula and S. Lavaitte, J. Nat. Prod, 49, 872-877 (1986).

32) Y. Kano, I. Yuhara, T. Yanagisawa, M. Sakurai, M. Konashima and K. Saito, Shoyakugaku Zaashi, 39, 88-89 (1985).

33) R. K. Grover and T. D. Moore, Phytopathology, 52, 876 (1962).

34) C. I. Bliss, Science, 79, 38 (1934).

35) N. K. Dubey, T. Tiwari, D. Mandin, H. Andriamboavonjy and J. P. Chaumont, Antifungal properties of Ocimum gratissimum essential oil (ethyl cinnamate chemotype), J. Fito., 71, 567569 (2000).

36) N. Dudareva, E. Pichersky, J. Gershenzon, Biochemistry of Plant Volatiles, Plant Physiology, 135, 1893-1902 (2004).

Table 1: Composition of the essential oil of aerial parts of Ocimum gratissimum

\begin{tabular}{|c|l|c|c|}
\hline S. No. & \multicolumn{1}{|c|}{ Compound } & KI & $\begin{array}{c}\text { Area percentage } \\
(96.27 \%)\end{array}$ \\
\hline 1 & 3-hexen-1-ol & 851 & 0.85 \\
2 & $\alpha$-thujene & 931 & 0.87 \\
3 & $\alpha$-pinene & 939 & 1.56 \\
4 & camphene & 953 & 2.65 \\
5 & 1-octane-3-ol & 978 & 0.26 \\
6 & $\beta$ - pinene & 980 & 1.36 \\
7 & $\alpha$-phellandrene & 1005 & 2.12 \\
8 & $\alpha$-terpinene & 1018 & 0.96 \\
9 & tert-butylbenzene & 1025 & 1.02 \\
10 & cis-8-methylclo $(4,3,0)$ non-3-ene & 1037 & 9.82 \\
11 & (E)-1,3,6,0 octatriene, 3,7,dimethyl & 1059 & 0.98 \\
12 & $\alpha$-benzenemethanol & 1060 & 0.86 \\
13 & $\gamma$-terpinene & 1062 & 0.96 \\
14 & $\alpha$-terpinolene & 1088 & 22.83 \\
\hline
\end{tabular}


International Journal of Trend in Scientific Research and Development (IJTSRD) ISSN: 2456-6470

\begin{tabular}{|c|c|c|c|}
\hline 15 & cyclopentane carboxylic acid 3- methylene & 1093 & 0.78 \\
\hline 16 & $2(1 \mathrm{H})$ Pyridinethione, 1 & 1095 & 0.56 \\
\hline 17 & trans-sabinene hydrate & 1097 & 0.96 \\
\hline 18 & 3- cyclohexen-1-ol & 1108 & 1.15 \\
\hline 19 & $\beta$-fenchyl alcohol & 1117 & 0.39 \\
\hline 20 & endo-borneol & 1165 & 0.69 \\
\hline 21 & myrtenol & 1194 & 0.65 \\
\hline 22 & bicyclo(3.1.1) hept-2-ene & 1265 & 0.77 \\
\hline 23 & eugenol & 1279 & 32.86 \\
\hline 24 & $\beta$-bourbonene & 1376 & 1.46 \\
\hline 25 & $\alpha$ - copaene & 1384 & 0.68 \\
\hline 26 & caryophyllene & 1418 & 1.32 \\
\hline 27 & $\beta$-gurjunene & 1433 & 0.87 \\
\hline 28 & $\alpha$ - humulene & 1454 & 0.65 \\
\hline 29 & germacrene-D & 1480 & 0.89 \\
\hline 30 & dodecatertraene & 1487 & 1.23 \\
\hline 31 & valencene & 1491 & 0.63 \\
\hline 32 & $\delta$ - cadinene & 1524 & 0.46 \\
\hline 33 & cis $-\alpha-$ bisabolene & 1533 & 0.89 \\
\hline 34 & caryophyllene oxide & 1581 & 0.52 \\
\hline 35 & phosphoric acid, dioctadecyl ester & 1618 & 0.76 \\
\hline
\end{tabular}


International Journal of Trend in Scientific Research and Development (IJTSRD) ISSN: 2456-6470

Table 2: Antifungal activity of essential oil

\begin{tabular}{|c|c|c|c|c|}
\hline \multirow[b]{2}{*}{ Fungus } & \multirow{2}{*}{$\begin{array}{c}\text { Concentration } \\
\text { of oil (\%) }\end{array}$} & \multicolumn{2}{|c|}{ Growth (In mm) } & \multirow{2}{*}{$\begin{array}{c}\text { Inhibition } \\
(\%) \\
\text { Over } \\
\text { Control }\end{array}$} \\
\hline & & Treatment & Control & \\
\hline \multirow{4}{*}{ Fusarium oxysporum } & 2.50 & 11.50 & 36.00 & 68.50 \\
\hline & 5.00 & 8.50 & 36.00 & 76.38 \\
\hline & 10.00 & 6.50 & 36.00 & 81.94 \\
\hline & 20.00 & 3.75 & 36.00 & 89.58 \\
\hline \multirow{4}{*}{ Fusarium solani } & 2.50 & 15.75 & 30.00 & 47.50 \\
\hline & 5.00 & 13.25 & 30.00 & 55.83 \\
\hline & 10.00 & 11.75 & 30.00 & 60.83 \\
\hline & 20.00 & 6.75 & 30.00 & 77.50 \\
\hline \multirow{4}{*}{ Macrophomina phaseolina } & 2.50 & 6.75 & 14.50 & 53.44 \\
\hline & 5.00 & 5.00 & 14.50 & 65.51 \\
\hline & 10.00 & 3.75 & 14.50 & 74.13 \\
\hline & 20.00 & 2.25 & 14.50 & 84.48 \\
\hline \multirow{4}{*}{ Rhizoctonia solani } & 2.50 & 14.50 & 19.75 & 26.58 \\
\hline & 5.00 & 13.00 & 19.75 & 34.17 \\
\hline & 10.00 & 11.75 & 19.75 & 40.50 \\
\hline & 20.00 & 6.75 & 19.75 & 65.82 \\
\hline
\end{tabular}

